Ilmu Dakwah: Academic Journal for Homiletic Studies Volume 11 Nomor 1 (2017) 53-72 DOI: 10.15575 /idajhs.v11i1.1356

http://journal.uinsgd.ac.id/index.php/idajhs ISSN 1693-0843 (Print) ISSN 2548-8708 (Online)

\title{
Dakwah Nabi Muhammad terhadap Masyarakat Madinah Perspektif Komunikasi Antarbudaya
}

\author{
Ahmad Anas ${ }^{1}$ dan Hendri Hermawan Adinugraha ${ }^{2 *}$ \\ ${ }^{1}$ UIN Walisongo, Semarang \\ 2 Universitas Dian Nuswantoro, Semarang \\ "hendri.hermawan@dsn.dinus.ac.id
}

\begin{abstract}
The purpose of this research is to know strategy and method propagation of Prophet Muhammad to society of Medina through intercultural communication approach. It was used descriptive qualitative research with historical approach. The result of research shows the Prophets propagation strategy towards the people of Medina are building mosque, creating new brotherhood relationship between Muhajirin and Ansor people, building cooperation and peace agreement, and forming Medina Charter as conflict resolution. the Prophets used personal, education, discussion, alms, mission and correspondence methods propagation to the Medina community.
\end{abstract}

Keywords : da wah, intercultural communication, Prophet Muhammad.

\section{ABSTRAK}

Tujuan penelitian ini untuk mengetahui strategi dan metode dakwah Nabi Muhammad terhadap masyarakat Madinah melalui pendekatan komunikasi antarbudaya. Penelitian ini menggunakan penelitian kualitatif deskriptif dengan pendekatan historis. Hasil penelitian menunjukkan strategi dakwah Nabi terhadap masyarakat Madinah dilakukan dengan cara membangun Masjid, menciptakan hubungan persaudaraan baru antara orang Muhajirin dan Ansor, membangun kesepakatan kerjasama dan perdamaian, dan membentuk Piagam Madinah sebagai resolusi konflik. Nabi juga melakukan dakwah dengan pendekatan komunikasi antarbudaya melalui metode personal, pendidikan, diskusi, penawaran, misi dan korespondensi.

Kata Kunci : dakwah, komunikasi antarbudaya, nabi Muhammad.

\section{PENDAHULUAN}

Dakwah yang dilakukan Nabi Muhammad SAW sebagai pembawa risalah kenabian untuk pembinaan masyarakat terbagai menjadi dua periode yaitu periode Mekah dan periode Madinah. Setiap periode dakwah Nabi Muhammad tersebut mempunyai karakteristik tersendiri sesuai dengan kondisi sosial masyarakat yang berbeda. 
Pada periode Mekah (610-622) Nabi Muhammad melaksanakan dakwah melalui pendekatan keluarga secara diam-diam dalam upaya memberi pelajaran dan petunjuk, kemudian secara bertahap pelaksanaannya dikembangkan secara terbuka. Hal ini dilakukan kerena melihat kondisi sosial masyarakat Mekah, yang mana kondisi masyarakat Mekah bercorak homogen, ini dapat dilihat masyarakat yang mendiami Mekah adalah bangsa Arab yaitu Arab Adnaniyat yaitu, salah satu keturunan Ismail yang bernama Adnan (Pulungan, 1996: 27). Sementara yang menguasai Makkah adalah suku Quraiys dan Nabi Muhammad merupakan anggota dari suku Qurays itu sendiri. Maka yang digunakan dalam dakwahnya adalah menggunakan pendekatan kekeluargaan. Dalam 10 tahun beliau berdakwah di kalangan penduduk Mekah dengan hasil yang jauh dari apa yang diharapkan.

Sementara pada periode Madinah Nabi Muhammad menghadapi masyarakat yang berbeda dengan masyarakat Mekah. Masyarakat Madinah adalah masyarakat yang, hal ini dapat dibuktikan dengan terdapatnya beberapa suku dan menganut juga beberapa agama. Penduduknya menjelang hijrah Nabi terdiri dari bangsa Arab dan bangsa Yahudi yang terbagi ke dalam beberapa suku. Sementara Suku bangsa Arab yang terkemuka adalah suku Aus dan suku Khazraj yang bermigrasi dari Arabia selatan. Bangsa Yahudi terdiri dari tiga suku utama Bani Quraizah, Bani Nadhir, dan Bani Qainuqa. Dalam segi Agama, masyarakat Madinah menganut beberapa agama yaitu agama paganisme (menyembah berhala) agama Yahudi dan agama kristen tetapi minoritas. Sejarah masuknya orang Yahudi ke Madinah gelombang pertama tidak banyak diketahui dengan pasti. Bisa jadi mereka tinggal tinggal di Madinah sejak sebelum masehi, tetapi gelombang perpindahan mereka yang utama terjadi akibat pengusiran oleh Kaisar Hardian (Kaisar Romawi) pada tahun 135M (Armstrong, 2002: 194-195).

Sebelum kedatangan Nabi, masyarakat Madinah selalu diliputi konflik antar sesama suku, dan masyarakat Madinah telah lama mengalami perang saudara. Klimaksnya terjadi pada peperangan $\mathrm{Bu}$ ats pada tahun $618 \mathrm{M}$ di mana hampir semua suku-suku Arab di Madinah terlibat di dalamnya, demikian juga suku-suku Yahudi, semuanya bersekutu dengan kelompoknya masing-masing (Engineer, 1999: 46). Hal ini disebabkan oleh pola struktur masyarakat Arab yang didasarkan pada organisasi klan, yang mengikat semua anggota keluarga dengan pertalian darah. Sistem hubungan ini menumbuhkan solidaritas yang kuat di antara keluarga-keluarga suku. Oleh para ahli disebut ashabiyat. Dengan semangat ini dapat menimbulkan chauvinisme yang mendalam. 
Dan yang terjadi adalah setiap suku merasa yakin mampu berdiri sendiri tanpa hidup berdampingan dengan suku lainnya, sehingga hampir tidak ada hubungan harmonis dan akrab antara suku-suku dengan yang lainnya serta tiap-tiap suku tidak mempunyai keprihatinan sosial terhadap nasib suku lain.

Ketika Nabi datang ke Madinah, strategi yang digunakan dalam dakwah agar tidak terjadi konflik dan permusuhan dalam masyarakat Madinah adalah, pembangunan masjid yang berfungsi selain tempat shalat juga sebagai sarana penting untuk mempersatukan kaum muslimin dan mempertalikan jiwa mereka dan juga sebagai tempat bermusyawarah merundingkan masalah-masalah yang dihadapi (Yatim, 2003: 26). Langkah lain yang dilakukan $\mathrm{Nabi}$ adalah menciptakan pondasi kemasyarakatan dengan mengikat tali persaudaran antara kaum muslim yang berhijrah mengikutinya (Muhajirun) dan penduduk setempat yang menerima klaim keNabiannya (Anshar). Untuk mempersatukan masyarakat Madinah yang majemuk, maka Nabi membuat Piagam Madinah, yang berupa kontrak sosial yang dibuat bersama oleh masyarakat Madinah. Dengan strategi yang digunakan tersebut akhirnya dalam kurun sepuluh tahun Nabi Muhammad mampu membangun sebuah masyarakat yang selama ini diliputi konflik bertahun-tahun menjadi sebuah masyarakat yang mempunyai peradaban tinggi, yaitu Islam sebagai agama yang rahmatal lil alamain (Baso, 1999: 21).

Perjalanan Nabi dalam melakukan dakwahnya, khususnya di Madinah tidak lepas dari proses komunikasi dengan masyarakat setempat. Dan Pada dasarnya proses dakwah tidak ubahnya sama dengan proses komunikasi dimana unsur yang terlibat di dalamnya pun sama, kecuali satu hal yaitu esensi pesannya yang berbeda. Kalau pesan dalam proses komunikasi bersifat umum, maka pesan dakwah adalah AlQur an dan Hadits, dengan muatan utamanya amar ma ruf nahi munkar, oleh karenanya proses dakwah mempunyai konsekuensi atau tanggungjawab moral yang harus dipikul oleh pelaksana (Triatmo, 2001: 76) . Dengan demikian dakwah dan komunikasi memiliki hubungan yang sangat dekat, sebab keberhasilan dakwah seorang da i sedikit banyak dipengaruhi oleh kemampuannya dalam mengkomunikasikan ajaran-ajaran Islam kepada masyarakat.

Masyarakat Madinah dikenal sebagai masyarakat yang majemuk baik agama, suku, budaya, dan ekonomi. Apabila diperhatikan masyarakat majemuk yang mempunyai latar belakang berbeda selalu menghadapi masalah etnosentrisme. Perbedaan itu merupakan akibat dari perbedaan folkways yang mereka miliki yang kemudian dapat mencuat dalam 
bentuk perpecahan yang mengarah disintegrasi antarbudaya, untuk mencegah terjadinya disintegrasi, maka komunikasi bertujuan membangun makna-makna yang sama terhadap setiap pesan yang berfungsi menumbuhkan integrasi dan solidaritas antar suku bangsa (Liliweri, 2011: 157). Praktek komunikasi dalam masyarakat majemuk biasanya dilakukan diantara komunikator dengan komunikan yang berbeda latar belakang budayaannya. Dan ini sama halnya dengan melakukan komunikasi antarbudaya. Komunikasi antarbudaya yaitu komunikasi yang dilakukan oleh dua orang atau lebih yang mempunyai budaya yang berbeda. dan penekananya pada bagaimana pengaruh budaya dalam komunikasi.

Secara umum penelitian yang mengkaji tentang dakwah Nabi Muhammad SAW sudah ada, namun secara sepesifik yang memfokuskan pada strategi dakwah Nabi Muhammad SAW terhadap masyarakat Madinah melalui pendekatan komunikasi antarbudaya belum ada. Agar penelitian ini dapat dipertanggungjawabkan originalitasnya maka perlu dilakukan penelusuran terhadap penelitian-penelitian terkait yang telah dilakukan oleh peneliti sebelumnya.

Pertama, penelitian yang dilakukan Lalu Kamaruddin (2006): Dakwah Nabi Muhammad SAW Pasca Perjanjian Hudaibiyah, hasil penelitian ini menyimpulkan bahwa pasca perjanjian Hudaibiyah adalah babak baru dalam dakwah Islam. Karena pada masa sebelumnya gerak dakwah sangat sulit berkembang. Dengan kondusifnya ajaran Islam, Rasulullah SAW. mulai mengembangkan dakwah Islam lebih luas dengan cara mengirimkan surat dan utusan-utusan kepada para pemimpin dunia.

Kedua, peneltian yang dilakukan oleh Ahmad Fathoni (2000) dengan judul : Eksistensi Dakwah Nabi Muhammad SAW dan Reaksi Kaum Qurais (Studi Histori Periode Mekkah), hasil penelitian ini adalah setelah Nabi Muhammad SAW menyampaikan dakwah Islam terhadap Kaum Qurais, membuat reaksi kemarahan yang luar biasa. Kaum Qurais berusaha menghentikan dakwah Nabi Muhammad SAW dengan berbagai macam cara. Namun Nabi Muhammad SAW tetap melanjutkan dakwahnya. Keberhasilan dakwan Nabi Muhammad SAW disebabkan oleh faktor dominan yang dimiliki oleh Nabi dan bimbingan wahyu dari Allah Swt. Kearifan dan kebijaksanaan Nabi merupkan kunci keberhasilan dakwah yang dilakukannya. Kearifan dan kebijaksanaan Nabi tercermin dari strategi dakwah yang bersifat persuasive, dengan memahami dan memperdulikan kondisi masyarakat sebagai objek dakwah. Pendekatan-pendekatan yang dilakukan oleh Nabi Muhammad

Ilmu Dakwah: Academic Joumal for Homiletic Studies 11(1) (2017) 53-72 
SAW merupakan upaya yang keras di samping kepasrahan kepada Allah, antara ikhtiar dan tawakal.

Ketiga, Hasil penelitian yang dilakukan oleh Imam Muslim (2008) dengan judul penelitian Dakwah Nabi Melalui Surat (Suatu Pendekatan Historis) .Penelitian ini menggunakan metodologi yang bersifat kepustakaan atau library research. yang diharapkan memperoleh analisis historis yang objektif mengenai sejarah pengiriman surat-surat dakwah Nabi Muhammad SAW. Penelitian ini mencoba mendeskripsikan motifmotif yang menyebabkan Rasulullah mengirimkan surat kepada para penguasa dan situasi politik pada saat itu. Hasilnya keputusan Rasulullah SAW. melakukan kegiatan dengan metode korespondensi berdasarkan motif-motif antara lain, imbas Perjanjian Hudaibiyah, Motivasi untuk mewujudkan Islam sebagai rahmatan lilalamin dan kekuatan di Madinah. Keputusan untuk melakukan upaya dakwah melalui surat ini sekaligus menunjukkan kemampuan Rasulullah dalam memanfaatkan situasi politik.

Penelitian ini bertujuan mengungkap strategi dan metode dakwah Nabi Muhammad terhadap masyarakat Madinah melalui pendekatan komunikasi antarbudaya. IMPLIKASI, MANFAAT, TUJUAN, jenis penelitian ini adalah penelitian kualitatif, maksudnya sebagai jenis penelitian yang temuan-temuannya tidak diperoleh melalui prosedur statistik atau bentuk hitungan lainnya (Strauss \& Corbin, 2003: 4). Sedangkan spesifikasi penelitian ini adalah kualitatif deskriptif. Pendekatan yang digunakan dalam penelitian ini adalah pendekatan historis. Dimana pendekatan historis yang bertujuan untuk mengetahui strategi dakwah Nabi Muhammad SAW di Madinah melalui pendekatan antarbudaya.

\section{HASIL DAN PEMBAHASAN}

\section{Struktur Sosial Masyarakat Madinah}

Periode Madinah adalah periode perjuangan dakwah Nabi Muhammad SAW ketika berada di Madinah. Periode ini disebut periode pembinaan kerajaan Allah dalam masyarakat manusia. Periode ini merupakan periode pembentukan masyarakat yang menerapkan ajaranajaran Islam, meskipun di antara warganya terdapat nonmuslim. Strategi dakwah Nabi Muhammad SAW pada periode Madinah adalah mensyiarkan Islam ke sejumlah wilayah. Menurut Syeikh Muhammad AlKhudhari, Nabi Muhammad SAW berdakwah di Madinah selama 9 
tahun, 9 bulan, dan 9 hari (Cholil, 2006: 83). Sehingga materi dakwah pada periode ini juga berkaitan tentang masalah kemasyarakatan dan kenegaraan. Ayat-ayat al-Qur an yang diturunkan juga berkaitan dengan masalah-masalah tersebut. Pada periode ini pula dakwah menjadi suatu kekuatan yang terorganisasi. Meskipun antara periode Mekah dan periode Madinah merupakan kesatuan yang tidak dapat dipisah-pisahkan, pencapaian pada periode Madinah jauh lebih gemilang dibandingkan dengan periode Mekah. Keberhasilan ini tidak dapat dilepaskan dari metode dan pendekatan yang digunakan oleh Nabi Muhammad SAW dalam berdakwah.

Komposisi penduduk di Madinah sebelum Islam Masuk berbeda dengan kota Mekah. Mekah yang yang berpenduduk bersuku-suku, bila dilihat dari karakteristik budaya agama memiliki sifat yang relatif homogen, yaitu sebagai penyembah berhala, sedangkan wilayah Madinah memiliki penduduk yang berasal dari berbagai suku, yang terdiri dari bangsa Arab yang terbagi dalam dua suku besar yaitu suku Aus dan Suku Khazraj yang bermigrasi dari Arabia selatan, dan bangsa Yahudi yang terbagi dalam beberapa suku. Yaitu Bani Quraizhat, Bani Nadhir, Bani Qunaiqa , Bani Tsa labat, Bani Hadh (Pulungan, 1996: 29). Mengenai asal usul mereka di Madinah, terdapat teori yang menyebutkan bahwa mereka bermigrasi dari Syam (syiria besar) pada abad I dan II Masehi, yaitu sesudah orang-orang Romawi menguasai Syiria dan Mesir pada abad I dan II sebelum Masehi, kehadiran mereka di Syiria dan Mesir membuat orang-orang Yahudi pindah ke Jazirah Arab (Umari, 1999: 64).

Dalam aspek keagamaan sebagaimana orang Arab Mekah, orangorang Arab Madinah juga melakukan penyembahan berhala, yaitu berhala manata (dewi fortuna atau dewi wanita) yang mereka yakini mempengaruhi nasib manusia. Dan ini disembah oleh suku-suku Azad, Aus dan Khazraj di Hijaz. Sedangkan masyarakat Yahudi adalah penganut Agama Yahudi. Sebagai Ahli Kitab dan penganjur monoteisme, mereka mencela tetangga mereka kaum Arab penyembah berhala sebagai pendekatan kepada Tuhan. Mereka juga memperingatkan kaum Arab bahwa kelak akan lahir seorang Nabi yang akan menghabisi mereka dan mendukung Yahudi. juga menginformasikan ajaran Taurat kepada kaum Arab tentang adanya hari kebangkitan, balasan dan hukuman atas perbuatan manusia dan bahwa Nabi terakhir yang akan lahir adalah pendukung agama monotoisme (Pulungan, 1996: 35).

Sekalipun ajaran itu tidak sampai membuat mayoritas orang-orang Madinah terpengaruh untuk mau menganut agama Yahudi, namun pengetahuan mereka tentang ajaran agama atau informasi itu menjadi 
salah satu faktor yang membuat mereka mudah menerima Islam setelah mereka bertemu dengan Nabi Muhammad. Selain penganut paganisme ada juga diantara kabilah-kabilah Arab yang menganut agama Masehi atau agama kristen, yaitu suku Judam dan udhra. sementara di Mekah kita mengenal beberapa orang dari Quraisy yang memeluk agama ini. Namun di antara mereka terdapat kelompok kecil yang masih berpegang pada agama hanifiyyat yang dibawa Nabi Ibrahim (Pulungan, 1996: 36). Oleh karenanya, dilihat dari struktur sosial dan kultur mereka, penduduk Madinah lebih cenderung bersifat majemuk dibanding Mekah. Mereka terdiri dari berbagai macam etnis dan kepercayaan serta memiliki tradisi adat istiadat tersendiri dari tiap-tiap sukunya.

Corak masyarakat Madinah yang majemuk ini bertambah kompleks dengan datangnya Islam kedaerah tersebut (sesudah hijrah). Para ahli berbeda pendapat dalam merumuskan golongan-golongan penduduk Madinah pascahijrah Nabi Muhammad beserta pengikutnya. Menurut Hasan Ibrahim yang dikutip Mahmuddin menyebutkan empat golongan, yaitu: Muhajirin; orang Islam yang Hijrah dari Mekah; Ansor, orang Islam dari Penduduk Madinah ; kaum Munafik dan Musyrik dan kaum Yahudi yang tinggal di Madinah. Akram Dhiyaudin Umari, membagi masyarakat Madinah berdasarkan pada keimanan yaitu: Mukminun, Munafiqun dan Yahudi (Umari, 1999: 77). Sementara itu menurut J.Suyuthi Pulungan menyebutkan bahwa penduduk Madinah terdiri dari, kaum Arab Madinah yang telah memeluk Islam yang disebut kaum Ansar, orang Arab Mekah yang muslim, disebut Kaum Muhajirin, orangorang Arab Madinah penganut paganisme, golongan Munafiq, golongan Yahudi yang terdiri dari berbagai suku baik bangsa Yahudi maupun orang Arab yang menjadi Yahudi dan penganut Kristen minoritas (Pulungan, 1996: 57). Selain informasi tersebut, juga terdapat di dalam alQur an yang dikategorikan ke dalam kelompok keyakinan, mereka disebut sebagai kaum Muhajirin, Anshar, Munafiq, Yahudi dan Nasrani. ${ }^{1}$

Kemajemukan penduduk Madinah adalah dilihat dari berbagai segi yaitu: 1) Dilihat dari segi kebangsaan, penduduk Madinah terdiri dari atas bangsa Arab dan bangsa Yahudi yang masing-masing terbagi dalam ke dalam beberapa suku. 2) Dilihat dari segi daerah, mereka adalah orangorang Arab Mekah, orang-orang Arab dan Yahudi Madinah. 3) Dilihat dari struktur sosial dan kultur, mereka sama-sama menganut system kesukuan tapi berbeda dalam adat istiadat. 4) Dilihat dari segi ekonomi, bangsa Yahudi adalah golongan ekonomi kuat yang menguasai pertanian,

${ }^{1}$ Lihat QS al-Taubah 9/100, 101 dan 117 dan al-Maidah 5/82 
perdagangan dan keuangan, sedangkan orang Arab adalah golongan kelas dua. 5) Dilihat dari segi agama dan keyakinan, mereka terdiri dari atas penganut agama Yahudi, pengabut agama Kristen minoritas, penganut agama Islam, golongan Munafiqun dan penganut paganisme (Musyrik) (Pulungan, 1996: 57)

Dengan demikian komposisi dan struktur masyarakat Madinah baik sebelum hijrah Nabi dan sesudah hijrah tidak mengalami perubahan dari majemuk menjadi homogen.

\section{Strategi Dakwah Nabi Muhammad pada Masyarakat Madinah}

Dengan diterimanya Nabi dan umat Islam oleh masyarakat Madinah, maka Nabi Muhammad SAW dapat melakukan penyebaran dakwah Islam dengan baik, karena mendapat dukungan dan sambutan dari Kaum Anshar, yaitu kelompok masyarakat yang menjadi penolong dan memberi perlindungan bagi umat Nabi Muhammad SAWdan Islam. Selain itu, umat Islam yang datang dari kota Mekkah ke Madinah atau kaum Muhajirin, ikut atif menyebarkan ajaran Islam kepada masayarakat Madinah. Melihat keadaan seperti itu, Nabi Muhammad SAW berusaha mempersiapkan langkah-langkah yang harus dilakukan untuk kepentingan dakwah dan pengembangan peradaban Islam. Langkahlangkah tersebut antara lain :

1) Membangun Masjid Sebagai Media dan Pusat Dakwah

Langkah pertama yang dilakukan Nabi Muhammad SAWsetibanya di Madinah adalah membangun sebuah Masjid. Masjid pertama dibangunnya di Quba pada sebuah tanah milik kedua anak yatim, yaitu Sahl dan Suhail bin Amr, yang sudah dibeli oleh beliau. Kiblatnya mengarah ke Bait al- Maqdis. Selanjutnya Nabi Muhammad SAW membangun sebuah masjid yang dikenal dengan nama Masjid Nabawi. Dan salah satu sudut masjid tersebut dijadikan sebagai tempat kediaman beliau, dengan dua kamar untuk kedua istri beliau Aisyah dan Saudah. Sementara itu kondisi bangunan masjid seperti yang digambarkan oleh Muhammad Husein Haekal (1984)sebagai berikut :

Masjid itu merupakan sebuah ruangan terbuka yang luas, keempat temboknya dibuat dari bata dan tanah. Atapnya sebagian terdiri dari daun kurma dan sebagian lagi dibiarkan terbuka, sebagian lagi dijadikan tempat fakir-miskin yang tidak punya tempat tinggal. Tidak ada penerangan dalam masjid pada malam hari. Hanya pada waktu isya diadakan penerangan dengan membakar jerami. Hal ini berjalan selama sembilan tahun. Sesudah itu baru digunakan 
lampu-lampu yang dipasang pada batang-batang (tiang) kurma yang dijadikan penopang atap itu. Tempat tinggal Nabi tidak mewah keadaannya dari pada masjid meskipun memang sepatutnya lebih tertutup.

Masjid yang dibangun tersebut tidak hanya berfungsi sebagai tempat melaksanakan ibadah sholat, juga dipergunakan sebagai pusat kegiatan pendidikan dan pengajaran keagamaan, mengadili berbagai perkara yang muncul di masyarakat, musyawarah, pertemuanpertemuan dan lain sebagainya. Dengan demikian, masjid juga berfungsi sebagai pusat kegiatan politik dan pemerintahan saat itu (AlMubarakfury, 2003: 248).

Dengan dibangunnya masjid ini, umat Islam tidak merasa takut lagi untuk melaksanakan sholat dan kegiatan-kegiatan keagamaan lainnya. Mereka tidak takut lagi dikejar-kejar oleh orang-orang musyrik dan orang-orang yang tidak suka terhadap Islam. Sejak saat itulah pelaksanaan sholat telah terumuskan dengan baik dan sempurna. Panggilan untuk melaksanakan sholat juga telah dikumandangkan. Orang yang pertama kali mengumandangkan panggilan sholat atau azan adalah Bilal bin Rabah. Dia diberi kepercayaan untuk melaksanakan azan karena memiliki suara yang sangat bagus dan merdu. Dari hari ke hari masjid Madinah menjadi ramai karena terus didatangi oleh para jamaah yang akan melaksanakan sholat berjamaah bersama Nabi Muhammad SAW (AlQahthani, 1994: 123).

Berdirinya masjid tersebut bukan saja merupakan tonggak berdirinya masyarakat Islam, juga merupakan titik awal pembangunan kota. Jalan-jalan raya di sekitar masjid dengan sendirinya tertata rapi, sehingga lama-kelamaan tempat itu menjadi pusat kota dan pusat perdagangan serta pemukiman. Nabi Muhammad SAW. sendiri sangat besar perhatiannya terhadap hal-hal yang berkaitan dengan pembangunan sarana jalan dan jembatan. Beliau bersama-sama umat Islam membangun jembatan-jembatan yang menghubungkan antara satu lembah dengan lembah yang lain sehingga masyarakat setempat dapat berhubungan dengan masyarakat lainnya.

Ramainya pembangunan di kota Madinah menyebabkan masyarakat yang berasal dari wilayah lain berdatangan ke kota baru ini, baik untuk tujuan perdagangan maupun tujuan-tujuan lainnya. $\mathrm{Hal}$ ini menyebabkan Madinah menjadi kota terbesar di jazirah Arabia.

2) Al-Mu akhat: Menciptakan Hubungan Persaudaraan Baru 
Sejak kedatangan Nabi Muhammad SAW. di Madinah, beliau selalu melakukan langkah-langkah positif demi perbaikan kehidupan masyarakat muslim Madinah khususnya dan masyarakat non muslim pada umumnya sehingga tercipta suasana aman dan damai. Langkah konkret lain yang dilakukan Nabi Muhammad SAW. adalah menciptakan persaudaraan baru antara kaum muslimin yang berasal dari Mekkah (kaum Muhajirin) dengan umat Islam Madinah (kaum Anshar) (Syalabiy, 1983: 40-41). Langkah tersebut dilakukan untuk memperkuat barisan umat Islam di kota Madinah (Ahmad, 2008: 370).

Untuk mencapai maksud tersebut, Nabi Muhammad SAW. mengajak kaum muslimin supaya masing-masing bersaudara demi Allah. Nabi Muhammad SAW. sendiri bersaudara dengan Ali ibnu Abi Thalib, Hamzah ibnu Abdul Mutholib bersaudara dengan Zaid, Abu Bakar bersaudara dengan Kharijah ibnu Zaid, Umar ibnu Khattab dengan Ithbah ibnu Malik al-Khazraji dan Ja far ibnu Abi Thalib dengan $\mathrm{Mu}$ adz ibnu Jabal. Muhajirin lainnya dipersaudarakan dengan kaum Anshar yang lain (Shihab, 2011: 514).

Dengan persaudaraan ini, Rasulullah telah menciptakan suatu persaudaraan baru, yaitu persaudaraan berdasarkan agama yang menggantikan persaudaraan yang berdasarkan darah. Dalam persaudaraan seperti ini, kaum Anshar memperlihatkan sikap sopan dan ramah dengan saudara mereka kaum Muhajirin. Kaum Anshar turut merasakan kepedihan dan penderitaan yang dialami saudarasaudara mereka dari kota Mekkah tersebut, karena mereka datang ke Madinah tanpa membawa harta kekayaan, sanak saudara, dan sebagainya. Sehingga mereka benar-benar menderita dan memerlukan pertolongan.

Sejak terciptanya tali persaudaraan di antara kaum Muhajirin dengan kaum Anshar, suasana semakin damai dan aman karena kaum Muhajirin kemudian banyak yang telah melakukan kegiatan perdagangan dan pertanian. Di antaranya adalah Abdurrahman bin Auf menjadi pedagang dan Abu Bakar, Umar, dan Ali menjadi petani. Nabi selalu menganjurkan kepada umat Islam untuk bekerja keras dalam mencari nafkah yang halal demi kehidupan mereka di Madinah (Shihab, 2011: 516-517).

3) Perjanjian dengan Yahudi Madinah: Membangun Kesepakatan Kerjasama dan Perdamaian

Langkah selanjutnya yang dilakukan Nabi Muhammad SAW adalah bermusyawarah dengan para sahabat, baik Muhajirin maupun Anshar unuk merumuskan pokok-pokok pemikiran yang akan 
dijadikan undang-undang. Rancangan ini memuat aturan yang berkenaan dengan orang-orang Muhajirin, Anshar, dan masyarakat Yahudi yang sedia hidup berdampingan secara damai dengan umat Islam. Undang-undang ini kemudian dikenal sebagai sebuah Piagam Madinah yang ditulis pada tahun $623 \mathrm{M}$ atau tahun ke- $2 \mathrm{H}$ (Ahmad, 2008: 387-388).

Di antara butir-butir perjanjian itu adalah sebagai berikut:

1. Kaum Muslimin dan kaum Yahudi hidup secara damai, bebas memeluk dan menjalankan ajaran agamanya masing-masing.

2. Apabila salah satu pihak diperangi musuh, maka mereka wajib membantu pihak yang diserang.

3. Kaum Muslimin dan Yahudi wajib saling menolong dalam melaksanakan kewajiban untuk kepentingan bersama.

4. Muhammad SAW Rasulullah adalah pemimpin umum untuk seluruh penduduk Madinah. Bila terjadi perselisihan di antara kaum Muslimin dan kaum Yahudi, maka penyelesaiannya dikembalikan kepada keadilan Nabi Muhammad SAW. sebagai pemimpin tertinggi di Madinah.

Piagam Madinah yang telah disepakati bersama itu menjadi titik tolak pembentukan negara yang demokratis, karena di dalam perjanjian tersebut terdapat poin-poin yang memberikan kebebasan kepada para penduduknya, termasuk penduduk yang bukan muslim untuk menjalankan perintah agamanya tanpa mendapat gangguan apapun.

Akan tetapi dalam perkembangan berikutnya, ternyata piagam tersebut tidak dilaksanakan dengan baik oleh orang-orang Yahudi, bahkan mereka melanggar perundang-undangan yang telah disepakati tersebut. Dengan demikian, maka piagam Madinah tidak dapat dilaksanakan dan hanya berlaku beberapa waktu saja.

4) Pembentukan Piagam Madinah Sebagai Resolusi Konflik

Agenda penting yang pertama kali Nabi Muhammad lakukan setelah berada di tengah-tengah komunitas Madinah adalah membangun masjid Quba dan menata kehidupan sosial politik masyarakat kota itu yang bercorak mejemuk. Pembangunan masjid dimaksudkan sebagai tempat aktivitas ritual keagamaan dilaksanakan sekaligus sebagai media Nabi dan komunitas muslim untuk membicarakan masalah-maslah sosial, politik dan ekonomi. Sebagai kota yang heterogen, Madinah dihuni oleh tiga komunitas yang berbeda yaitu komunitas Muslim, Yahudi dan komunitas Paganis. Penataan internal ummat Islam yang dilakukan oleh Nabi adalah 
mempersatukan visi dan misi kehidupan keberagamaan kelompok Ansor dan Muhajirin dengan identitas kesatuan teologis. Setelah penataan internal selesai adalah dengan melakukan berbagai negoisasi politik untuk membuat bingkai kehidupan dalam kebersamaan sebagai komunitas Madinah secara umum, khususnya dengan komunitas Yahudi dengan disepakatinya Piagam Madinah.

Hijrahnya Nabi Muhammad menandai tidak hanya perubahan dramatik dalam pertumbuhan jumlah ummat Islam dan pembentukan masyarakat politik di Madinah, tetapi juga peralihan yang signifikan dalam materi pokok dan missi Nabi. Secara umum dapat disepakati bahwa periode Makkah, ajaran Islam lebih banyak berbicara persoalan moral keagamaan dan tidak menyinggung persolan hukum dan sosial politik secara luas. Persoalan hukum dan sosial politik baru banyak disinggung ketika periode Madinah. Hal ini disebabkan karena pada periode Madinah al-Qur an as-Sunnah harus memberikan respon terhadap kebutuhan sosial politik yang konkrit di suatu komunitas (An-Naim, 1994: 28).

Dalam konteks negara Madinah Nabi Muhammad sendiri memainkan peran kunci dalam perkembangan komunitas muslim. Di samping beliau seorang pemimpin keagamaan, beliau juga tampil sebagai kordinator utama persoalan-persoalan politik administrative dan komandan militer. Semua dimensi kehidupan Nabi adalah subyek pesan wahyu Allah. Nabi telah menunjukkan ketundukan yang kuat terhadap wahyu dan pada saat yang sama, beliau fleksibel dalam menghadapi persoalan-persoalan baru. Kemampuannya untuk dapat menyesuaikan secara tepat adalah faktor pemersatu bagi komunitas muslim. Realitas: social Madinah yang penuh dengan komflik secara politis sangat menguntungkan posisi Nabi Muhammad untuk melakukan gerakan politik (dakwah al-siyasy) dan mengambil peran dalam proses rekonsiliasi di antara masyarakat Yatsrib.

Rivalitas suku Arab Aus dan Khazraj dalam konteks perebutan ruang dominasi antara keduanya membuat mereka masing-masing membuat scenario berebut untuk berinisiatif menemui $\mathrm{Nabi}$ Muhammad dalam rangka masuk Islam dan memperoleh legitimasi yang kuat dan ini mereka butuhkan sebagai bagian cara meningkatkan dominasinya. Langkah kongkrit yang mereka lakukan adalah dengan membangun komitmen dengan Nabi Muhammad sebagai tokoh fenomenal yang terus bersinar. Dukungan orang Madinah terhadap Rasulullah dituangkan dalam sebuah penyataan kesetiaan pada Rasulullah yang kemudian peristiwa sejarah ini dikenal dengan bai at 
Dakwah Nabi Muhammad terhadap Masyarakat Madinah Perspektif Komunikasi Antarbudaya

aqabah. Peristiwa ini terjadi dua kali yaitu terjadi pada tahun 621 dan 622 yang kemudian disebut baiat aqabah I dan II (Pulungan, 1977: 79). Baiat aqabah merupakan persekutuan politik dan bagi Nabi merupakan investasi politik yang luar biasa dalam konteks pembumian Islam

Implikasi dari bai at aqabah adalah proteksi untuk kerjasama yang saling menguntungkan. Dalam tradisi suku Arab, proteksi menjadi suatu hal yang penting untuk sebuah jaminan perlindungan di tengah system kesukuan yang saling berebut dominasi dengan parameter kekuatan. Dari sini jelas bahwa lahirnya Piagam Madinah bukanlah kecelakaan sejarah (historical accidence) tetapi perjalanan sejarah yang sudah direncanakan (by desain) sebagai sebuah skenario untuk membumikan dakwah Islamiyah. Sebagai sebuah kontrak sosial, Piagam Madinah secara keseluruhan memuat 47 pasal itu menggambarkan semangat kebersamaan, toleransi antar umat beragama dan dialog dengan prinsip kesetaraan.

Dari semua pasal yang termuat dalam piagam Madinah menurut Munawir Sjadzali (Sjadzali, 1993: 15) prinsip dasarnya memuat dua hal pokok, yaitu: Semua pemeluk Islam, meskipun berasal dari banyak suku merupakan satu komunitas. Hubungan antar sesama anggota komunitas Islam dengan anggota komunitas lain didasarkan pada nilai-nilai, (a) bertetangga baik, (b) saling membantu dalam menghadapi musuh bersama, (c) membela yang teraniaya, (d) saling menasihati, dan (e) menghormati kebebasan beragama.

Perjanjian ini merupakan upaya Nabi Muhammad melakukan pembaharuan secara cermat dan bijaksana terkait dengan berbagai konflik di Madinah. Tentang hal ini R.A Nicholson yang dikutip Asghar Ali Engenerr menyatakan:

Tak seorangpun dapat mengkaji dokumen ini tanpa terkesan oleh kejeniusan politik penyusunnya. Perjanjian ini merupakan buah pikiran yang arif dan bijaksana sekaligus merupakan terobosan baru. Muhammad tidak secara terbuka menyerang kemandirian para suku yang ada, namun sesungguhnya beliau menghantamkanya dengan cara memindahkan pusat kekuasaan yang ada di kepala suku ke tangan masyarakat. Komunitas muslim adalah mitra aktif yang dalam waktu dekat akan mendominasi negara baru yang baru saja dibentuk ((Engineer, 1999: 34). 
Perubahan struktur yang radikal dari Piagam Madinah adalah mengubah konfederasi kesukuan menjadi masyarakat baru yang dikendalikan oleh ajaran-ajaran moral dengan instrumentasi hukum yang jelas. Ajaran Yahudi lebih memfokuskan pada ajaran hukum, sementara Nasrani hanya mendakwahkan persaudaraan spiritual saja. Dengan demikian, ajaran Islam dibangun diatas hukum dan moral secara beriringan. Dari sisi politik, Piagam Madinah menggambarkan sebuah doktrin politik religius (politico-religious doctrine) yang didasarkan pada persaudaran universal. Negara ideal Islam adalah komunitas iman atau ummah, tanpa memandang ras, atau pertimbangan geografis.

Melalui dialog, Islam memberi ruang dan kesempatan besar bagi terjadinya pencerahan umat karena nilai-nilainya selalu kontekstual. menyapa kehidupan sesuai karakter kehidupan yang sangat beragam. Dialog akan meletakkan: umatnya kepada kondisi untuk selalu memahami kehidupan dan umat manuasia secara utuh dan menyikapinya berdasarkan watak asalnya. Konsekuensinya, pluralisme dalam keberagamaan umat Islam menjadi kemestian untuk dikembangkan.

Dialog sebagai proses untuk menelanjangi diri sendiri, sekaligus upaya melihat orang, kelompok, atau subyek lain sebagaima apa adanya akan mengantarkan umat Islam untuk memahami segala sesuatu yang ada luar diri sendiri secara arif. Dengan demikian hal itu akan menjauhkan mereka dari sikap mereduksi keberadaan yang lain dalam kepentingan sempit mereka sendiri. Pada gilirannya hal itu akan menumbuhkan secara kokoh sikap menghormati subyek lain dalam bentuk perwujudan perilaku yang dapat membawa kebaikan dalam kehidupan. Piagam Madinah telah mengganti ikatan kekeluargaan dan kesukuan yang individual menjadi ikatan persaudaraan. Piagam Madinah juga mengakui eksistensi Yahudi sebagai komunitas yang berdiri sendiri dan hidup berdampingan dengan umat Islam.

Pluralisme keagamaan bagi syari at Islam bukanlah sekedar masalah mengakomodasi berbagai klaim kebenaran agama dalam wilayah keimanan pribadi seseorang. Pluralisme religius secara inheren selalu merupakan masalah kebijakan publik dimana setiap pemerintahan Islam harus mengakui dan melindungi hak pemberian Tuhan kepada setiap pribadi untuk menentukan sendiri nasib spiritualnya tanpa paksaan. Pengakuan terhadap kebebasan hati nurani dalam hal keimanan adalah titik utama konsep al-Qur an mengenai pluralisme religius, pluralisme antar agama maupun intra agama. 
Beberapa diktum pasal dalam Piagam Madinah yang menggambarkan penghormatan hak beragama antara lain tercermin pada pasal 2 dan 25. Sedangkan pasal yang secara eksplisit menjelaskan hubungan yang koeksistensi secara social antara lain tergambar pada pasal 37. Dalam Pasal 2 ditegaskan bahwa Kaum muslimin adalah ummat yang satu utuh, mereka hidup berdampingan dengan kelompok-kelompok masyarakat yang lain.

Pada pasal 25 tergambar bahwa sebagai satu kelompok, Yahudi bani Auf hidup berdampingan dengan kaum muslimin. Kedua belah pihak memiliki agama masing-masing. Demikian pula halnya dengan sekutu dan diri masing-masing. Bila diantara mereka ada yang melakukan aniaya dan dosa dalam hubungan ini, maka akibatnya akan ditanggung oleh diri dan warganya sendiri. Sedangkan pada Pasal 37 disebutkan Kaum Yahudi dan kaum muslimin membiayai pihaknya masing-masing. Kedua belah pihak akan membela satu dengan yang lain dalam menghadapi pihak yang memerangi kelompok-kelompok masyarakat yang menyetujui perjanjian piagam Madinah ini. Kedua belah pihak juga saling memberi saran dan nasihat dalam kebaikan tidak dalam perbuatan dosa.

Piagam Madinah merupakan salah satu bukti histories yang terdokumentasikan secara tekstual sebagai sumber normative sekaligus model actual bagaimana masyarakat muslim mendesain pola hubungan antar ummat beragama. Melalui Piagam Madinah penataan hubungan antar agama dalam Islam telah diberi tauladannya oleh Rasulullah saw setelah hijrah dari Makkah ke Madinah ( al-Madinah, kota par excellence) (Raharjo, 1993: 25-29). Dari nama yang dipilih oleh Nabi sebagai kota hijrahnya, menunjukan rencana Nabi dalam rangka mengemban misi sucinya dari Tuhan, yaitu menciptakan masyarakat yang berbudaya tinggi, yang kemudian menghasilkan suatu entitas sosial politik sebuah negara. Negara Madinah yang dipimpin oleh Nabi saw adalah model bagi hubungan antara agama dalam Islam. Sedangkan substansi dari Piagam Madinah menggambarkan adanya proses pelembagaan kesadaran masyarakat Madinah untuk meletakan fondasi relasi masyarakat yang majemuk dengan spirit hidup berdampingan dan damai (peace building community).

\section{Dakwah Nabi Muhammad Perspektif Komunikasi Antarbudaya}

Di dalam al-Qur an Allah menegaskan bahwa Muhammad adalah seorang Rasul, sebagai Rasul beliau bertugas menyampaikan wahyu yang diterimanya kepada manusia. Apabila dilihat dalam perspektif 
komunikasi antarbudaya, keberhasilan Nabi dalam menyampaikan pesanpesan Islam kepada masyarakat Madinah yang berlatar majemuk meliputi, suku, bangsa, agama maupun adat istiadat tidak lain karena kemampuan beliau dalam menyampaikan pesan-pesan Tuhan dan mengajak orang lain untuk melaksanakan pesan-pesan tersebut dengan cara yang memikat dan efektif.

Komunikasi antarbudaya merupakan komunikasi yang dilakukan dua orang atau lebih, yang mempunyai perbedaan latar belakang kebudayaaan. Nabi Muhammad dalam melakukan dakwahnya di Madinah menghadapi masyarakat yang mempunyai latar belakang budaya yang berbeda-beda. Dalam uraian bab sebelumnya tampak bahwa masyarakat Madinah bersifat majemuk, kemajemukannya adalah dalam hal etnis dan bangsa, asal daerah, ekonomi, agama dan keyakinan. Ini berarti bahwa Nabi Muhammad secara tidak langsung melakukan proses komunikasi antarbudaya.

Kondisi struktur masyarakat Madinah yang demikian menyebabkan tiap golongan memiliki cara berfikir dan bertindak sendiri dalam mewujudkan kepentingannya sesuai dengan filosofi hidupnya yang dipengaruhi oleh keyakinan yang dianutnya, kulturnya dan tuntutan situasinya. Hal ini telah terbukti pada kelompok-kelompok sosial di Madinah sebelum Islam yang selalu bermusuhan dan berperang sebagaimana telah diuraikan pada bab sebelumnya. Kondisi seperti inilah yang dihadapi Nabi ketika melakukan dakwahnya.di Madinah.

Keberhasilan melakukan komunikasi dengan seseorang, tidak hanya dibutuhkan pesan yang verbal tetapi juga non verbal yang berupa sikap dan tingkah laku, terlebih ketika antara komunikator dan komunikan memiliki latar belakang kebudayaan yang berbeda. Maka yang terpenting dalam melakukan komunikasi terhadap orang yang memiliki budaya yang berbeda adalah menggunakan pesan non verbal disamping pesan verbal.

Pada dasarnya, manusia cenderung memerlukan sosok teladan dan panutan yang mampu mengarahkan manusia pada jalan kebenaran dan dapat memberikan motivasi jiwa dalam membentuk kepribadian yang sempurna. Oleh karena itu, dalam berdakwah agar yang diinginkan tercapai, maka seorang pelaku dakwah harus memperhatikan prinsip keteladanan. Dakwah Rasulullah selalu mendahulukan sikap persahabatan dan menunjukan sikap simpatik, terutama terhadap masyarakat non muslim Nabi mengajak mereka dengan uluran tangan persahabatan. Dari uraian tersebut bahwa Nabi Muhammad dalam menyampaikan pesan-pesan Islam tidak hanya sebatas ucapan saja, tetapi dibarengi dengan sikap, dan tingkah laku yang sesuai dengan ucapannya. 
Ketika seseorang berkomunikasi dengan orang lain, ia dihadapkan dengan dengan bahasa, aturan dan nilai yang berbeda, maka sulit baginya memahami komunikasi mereka bila ia sangat etnosentrik yaitu memandang budaya orang lain dengan perspektif budaya kita sehingga yang terjadi menyalahkan orang lain yang berbeda budaya. Maka dalam melakukan komunikasi antarbudaya kita harus memahami dan mengerti budaya orang lain, sehingga dalam melakukan komunikasi bisa berhasil sesuai dengan tujuan.

Nabi Muhammad dalam melakukan dakwahnya di Madinah yang mempunyai latar belakang budaya berbeda, menghindari sifat etnosentrisme, yang membawa sebuah perpecahan, tetapi sebaliknya Nabi berinteraksi dan berkomunikasi terhadap masyarakat Madinah penuh kasih sayang, dan dalam segala penuturannya selalu menggunakan kalimat-kalimat yang sopan, yang mengandung hikmah nasihat, tidak membedakan dari kalangan apa mereka berasal, sesuai dengan firman Allah Q.S. Asy-Syu ara: 215 yang artinya : Dan rendahkanlah dirimu terhadap orang-orang yang mengikutimu, yakni orang-orang yang beriman. Hal ini dapat dilihat beberapa strategi yang telah diuraikan diatas, bahwa Nabi Muhammad berusaha mencari persamaan bukan perbedaan baik terhadap muslim maupun non muslim.

Upaya-upaya untuk mencari persamaan dapat kita temui dalam strategi yang telah diterapkan Nabi dalam dakwahnya, sistem persaudaran yang diciptakan Nabi bukan diikat dengan kesamaan keluarga atau keturunan tetapi diikat dengan kesatuan akidah atau keimanan. Sementara upaya yang dilakukan Nabi untuk menyelesaikan persoalan eksternal Nabi Muhammad membuat perjanjian yang mengikat seluruh penduduk Madinah. perjanjian ini dikenal dengan Piagam Madinah. dalam perjanjian tersebut, Nabi Muhammad telah mengikat dan menjamin akan keamanan jiwa,harta dan agama orang-orang non Muslim. Nabi memperlakukan mereka sama tanpa ada perbedaan antara satu kabilah dengan kabilah lainnya. Dalam Piagam tersebut Nabi memberikan hak dan kewajiban masing-masing kabilah serta kebebasan beraqidah dan menekankan agar masing-masing kabilah agar saling membantu (Pulungan, 1996: 64).

Dalam Piagam tersebut ternyata Nabi tidak membeda-bedakan masing-masing kabilah baik yang muslim maupun non muslim, mereka semua di beri hak dan kewajiban yang sama. Ini berarti Nabi bahwa Nabi dalam dakwahnya menjauhi sikap etnosentisme. Begitu juga ketika beliau mendirikan masjid sebagi tempat ibadah sekaligus tempat pertemuan, arah kiblatnya di hadapkan ke arah Yerussalem, ini dimungkinkan untuk 
mencari persamaan. Seperti yang ungkapkan oleh Thomas W. Arnold bahwa di dalam bersembahyang pada mulanya berkiblat ke arah Yerusalem. Sebagai taktik untuk menarik perhatian kaum Yahudi (Arnold, 1981: 24).

Dengan demikian Nabi dalam melakukan dakwah di Madinah yang notabenenya masyarakat majemuk menggunakan kaidah-kaidah Komunikasi antarbudaya, yaitu apabila berkomunikasi dengan orang yang berbeda budaya seraya memahami budaya orang lain, dan di harapkan bisa beradaptasi dengan lingkungannya. Beradaptasi bukan berarti menyetujui dan mengikuti semua tindakan orang lain, melainkan mencoba memahami alasan di baliknya tanpa tertekan oleh situasi (Mulyana, 2004 : 10). Dan menjauhi sikap-sikap etnosentrisme yaitu stereotip, jarak sosial dan diskriminasi. Serta mencari persamaan bukan perbedaan seperti yang diungkapkan oleh Milton J. Bennet makin besar kesamaan kita dengan dengan mereka, makin dekat mereka kepada kita; makin besar ketidaksamaan, makin jauh mereka dengan kita (Mulyana \& dkk, 2000: 76). Dan ternyata Nabi telah mempraktekan kaidah-kaidah komunikasi antarbudaya tersebut.

Dengan pendekatan dakwah yang penuh dengan persahabatan dan toleransi yang tinggi, kedatangan Islam di Madinah dapat diterima dengan baik oleh masyarakat Madinah yang majemuk. Keberhasilan yang sangat luar biasa yang dilakukan Nabi Muhammad terletak pada kemampuan beliau menciptakan sendi-sendi dasar bagi terbentuknya Islam yang rahmatan lil alamin. Setidaknya ada dua prinsip yang dipegang Nabi dalam membangun masyarakat Madinah yang tertuang dalam piagam Madinah pertama prinsip kesederajatan dan keadilan, kedua prinsip inklusivisme (keterbukaan). Prinsip kesederajatan dan keadilan ini mencakup semua aspek, baik politik, ekonomi, maupun hukum. Dalam aspek politik Nabi mengakomodasikan seluruh kepentingan. Semua rakyat mendapat hak yang sama dalam politik. Mereka tidak dibedakan berdasarkan suku ataupun agama. Seluruh lapisan masyarakat duduk sama rendah berdiri sama tinggi. Ideologi sukuisme dan nepotisme tidak dikenal Nabi. Sementara dalam aspek ekonomi, Nabi menerapkan ajaran egalitarianisme. Dan dalam as pek hukum Nabi tidak membedakan orang atas, orang bawah ataun keluarganya sendiri. Sedangkan prinsip inklusivisme atau keterbukaan adalah kerendahan hati untuk tidak merasa selalu benar, kemudian kesediannya mendengar pendapat orang lain untuk diambil dan diikuti mana yang terbaik. Inilah yang di praktekan Nabi dalam membangun Masayrakat Madinah.

Ilmu Dakwah: Academic Joumal for Homiletic Studies 11(1) (2017) 53-72 
Dengan prinsip tersebut Islam mampu menempatkan diri sebagai sesuatu yang unik, yang berbeda dengan agama lain. Salah satu pandangan berakar dalam pandangan seorang muslim adalah bahwa agama Islam merupakan agama yang universal, untuk sekalian umat manusia. kesadaran ini akan melahirkan sikap-sikap sosial keagamaan seperti sikap toleransi, kebebasan, keterbukaan, keadilan dan kejujuran yang jarang dimiliki oleh pemeluk agama lain, kecuali setelah munculnya zaman modern dengan ideologi modern.

Prinsip-prinsip dasar diatas seperti sikap inklusif, plural dan toleran yang telah dicontohkan pada zaman Nabi di Madinah, telah menjadi prinsip-prinsip atau ideology modern. Dan belakangan ini menjadi isu yang menarik untuk diperbincangkan yakni ide tentang konsep masyarakat madani, yang merujuk pada prinsip-prinsip di atas.

Perbedaan agama di Madinah, bukan menjadi faktor penghalang bagi hubungan harmonis. Bahkan menjadi bukti bahwa Islam bisa menjadi rahmat lil alamin, dimana masyarakat Islam dan tetangga Islam (non muslim) ikut merasakan kedamian yang diberikan Islam. Islam sebagai agama salam, yang menebarkan rasa damai menempatkan manusia dalam prioritas yang utama, artinya penghargaan manusia itu tidaklah dibeda-bedakan baik ras maupun agamanya. Memang benar, Islam mengakui adanya perbedaan dalam bahasa, agama dan ras tetapi tidaklah hal itu merupakan dasar perbedaan untuk tidak menjalin kerja sama sesuai dengan al-Qur an sendiri, bahwa terciptanya hal tersebut adalah hal tersebut adalah untuk saling mengenal sehingga dapat sharing of information dan transfer of idea sehingga diharapkan dapat terbentuk masyarakat dunia yang damai dan padu (wahdah inssaniyah) (Tasmara, 1992: 42).

\section{PENUTUP}

Berdasarkan uraian-uraian dari pembahasan di atas dapat disimpulkan bahwa: Strategi dakwah Nabi Muhammad terhadap masyarakat Madinah adalah sebagai berikut : a). Membangun Masjid sebagai media dan pusat dakwah, b). Al-Muakhat : Menciptakan hubungan persaudaraan baru atara orang Muhajirin dan Ansor, c). Perjanjian dengan Yahudi Madinah: Membangun kesepakatan kerjasama dan perdamaian, d). Pembentukan Piagam Madinah sebagai resolusi konflik. Kemudian, dakwah Nabi Muhammad terhadap masyarakat Madinah melalui pendekatan komunikasi antarbudaya dalam menyebarkan agama Islam melalui metode-metode beliau mampu 
mewujudkan Islam sebagai rahmatan lil alamin. Walaupun tantangantantangan yang dilakukan oleh kaum Yahudi Madinah untuk menghentikan dakwah Nabi begitu keras, namun Nabi Muhammad sanggup menghadapi tantangan tersebut. Hal itu terbukti sekarang ini, keseluruhan dari penduduk Madinah beragama Islam. Ini adalah bukti agama Islam yang diperjuangkan oleh Rasulullah adalah agama yang benar dan menunjukkan efektifitas dakwah Rasulullah menggunakan komunikasi antarbudaya.

\section{DAFTAR PUSTAKA}

Ahmad, M. R. (2008). Biografi Rasulullah: Studi Analisis Berdasar Sumber-sumber Autentik. Jakarta: Qisthi Press.

Al-Mubarakfury, S. S. R. A.-R. M. (2003). Batsun Fis-Sirah AnNabawiyah Ala Shahibiha Afdhalish-Shalati Was-Salam. Penerjemah Kathur Suhardi, Sirah Nabawiyah cetakan ke-13. Jakarta: Pustaka Al-Kautsar.

Al-Qahthani, S. B. A. B. W. (1994). Al-Hikmatu Fid Da wah Ilallah Ta ala, diterjemahkan oleh Maskur Hakim, Da wah Islam Da wah Bijak. Jakarta: Gema Insani Press.

An-Naim, A. A. (1994). Toward an Islam Reformation Civil Liberties Human Right and international Law, Terj. A Suaidi. Dekonstruksi Syariah : Wacana kebebasan sipil, HAM dan internasional dalam Islam. Jogjakarta: LKiS.

Armstrong, K. (2002). Muhammad A Biografi of the prophet, di terjemahkan oleh Sirikit Syah, Muhammad Sang Nabi, Sebuah Biografi Kritis. Surabaya: Risalah Gusti.

Arnold, T. W. (1981). The Preaching of Islam, alih bahasa A. Nawawi Rambe, Sejarah Dakwah Islam. Jakarta: Widjaya.

Baso, A. (1999). Civil Society Versus Masyarakat Madani. Bandung: Pustaka Hidayah.

Cholil, M. (2006). Kelengkapan Tarikh Nabi Muhammad, Jil. 1. Jakarta: Gema Insani Press.

Engineer, A. A. (1999). The Origen and Devolopment of Islam, di terjemahkan Imam Baehaqi Asal Usul dan Perkembangan Islam. Yogyakarta: Insist dan Pustaka Pelajar.

Fathoni, A. (2000). Eksistensi Dakwah Nabi Muhammad SAW dan Reaksi Kaum Qurais (Studi Histori Periode Mekkah).

Haekal, M. H. (1984). Sejarah Hidup Muhammad, diterjemahkan Hayat Muhammad oleh Ali Audah. Jakarta: Tintamas.

Kamaruddin, L. (2006). Dakwah Nabi Muhammad SAW Pasca 